\title{
安慧の「唯識性」のもつ二義性について 初期唯識思想と独我論
}

\section{源重 浩}

\section{1. 序論}

初期唯識思想の解釈の一つの立場である古唯識は, 独我論の切り口で見る時, どのように理解さるべきであろうか. 今回は古唯識の代表的思想家である安慧の 立場を検討する, 結論を先取りして述べると, 安慧の唯識解釈には, 「見道」の悟 りの究極において, 独我論ではないかという疑念を消滅させるものが語られている, と考えられる，安慧によると，「見道」の悟りにおいて瑜伽行者は「唯識性」に到 達するが,「唯識性」には「心の内なるもの」と「無心」との二つの境位が語られ ている。この「無心」の境位において「何かあるもの」即ち「実在」が現前し， そのことによって独我論ではないかという疑念は消滅する，安慧の主として『唯 識三十頌釈論 Trimísikāvijñaptibhāsya $a^{1} 』$ を検討することで, このことを論証する.

尚, 本稿は拙論（源，2017）の叙述とある程度重複している。この拙論は比較 的長文で, 議論も多岐にわたり，「唯識性」の二義についての叙述も圥漫である. 本稿の狙いは,「唯識性」の二義についての議論をコンパクトな形で整理し読者 の理解を容易ならしめ，更に「二義」のうちの「無心」によって成立する「実 在」が, 独我論ではという疑念を消滅させること, かつ, この「実在」は西洋哲 学の「実在」とかなり相違することに言及する点にある.

\section{2. 第28頌および注釈について}

安慧は『唯識三十頌釈論』第 28,29 頌の注釈部分において独我論の議論に関し て重要な叙述をしている. 入無相方便と呼ばれる宗教経験のクライマックスを示 す，世親の『唯識三十頌』第28頌の和訳は以下のとおりである2).

しかし, 識（智）が所縁を全く受け取らないその時に, 唯識性に安住している. 所取の 無においてそれを能取しない故に。(28abcd) 
この第 28 頌に対する安慧の注釈の冒頭部分の和訳は以下のとおりである.

教説の所縁, 教誡の所縁, 通常の色声などの所縁を, 識（智）は, 心より外に（bahiścittān）, 受け取らない，見ない，把握しない，執着しない．対象（境）をあるがままに見るからで あって, 生来盲目の [人の]如くに [見ないの] ではない ${ }^{3)}$. その時に, 識の取の断捨があり, また自らの心の法性において安住しているのである. まさにこの点について理由を云う. 「所取の無においてそれを能取しない故に $(28 \mathrm{~d}) 」$ と. 所取が存在する場合には能取が存在 する. しかし所取が存在しない場合にはそうではないと. 所取が存在しない場合には能取 の無に帰着する．単に所取の無のみではない．実にかくの如く所縁と能縁が完全に平等な る無分別の出世間智が生じる. 所取能取の執着随眠が断ぜられ，自らの心の法性において まさに心が安住するのである.

ここに述べられているのは意味を波むと以下の通りであろう。唯識たることに 心が安住するその時には，識（智）は唯識性においてのみ通常の色声などを見る. つまり，常識的なかたちでは見ない。すなわち普通我われが見ているようなかた ちでは見ないのである。しかし，「見ない」と云っても，対象（境）をあるがまま に見ているのであって，生来盲目の人が何も見ないのとは違うのである。即ち, 瑜伽行者は生まれつき眼の見えない人が何も見ていないのとは違って何かを見 ている, と安慧は云っている。この時は「所取能取」，「見られるもの見るもの」 grāhyagrāhakaの二元性が消滅している時であるから, 所取能取が平等である無 分別の出世間智が生じている. この時自己は「無」になっており，入無相方便の 宗教経験はクライマックス（根本智）に達している.

\section{3. 第29頌および注釈}

さらに世親の第29頌の和訳は以下の通りである.

それは無心 ${ }^{4)}$ である，無得である，そしてそれは出世間智である．二重の鹿重を断捨す ることからの所依の転換である.（29abcd）

これに対する安慧の注釈の和訳は以下のとおりである.

それ故, この二頌によって見道より始まって, 更なる勝れたものに向かって行くことに よって, 唯識に悟入した瑜伽行者たちにとっての果の円満成就が明示されている. その中 で能取の心はなくなるから, また所取の境を取らないからである.「これは無心であり, 無 得である. (29a)」世間の人々に蓄積されてきていないから, 世間に向かって活動すること がないから．そして無分別なるもの故，世間より超出している．だから「それは出世間智 
であると云われている．（29b）」かの智の直後に所依の転換があると知らせるために [世親 は］云う．「所依の転換であると. (29c)」ここで所依とは一切の種子を有するアーラヤ識 である，それの転換とは，それは鹿重と異熟と二つの習気がないことによって，止滅があ る時に, 活動性と法身と無二の智が生じることによって, 転換することである. 更に, そ の所依の転換は何を断捨することによって得られるのか. 故に云う.「二重の鹿重を断捨 する故に（29d)」二重というのは，煩悩障である鹿重と所知障である鹿重とである．鹿 重とは, 所依の不可塑性 ${ }^{5)}$ である. 更にそれは, 煩悩と所知の二つの障にとっての種子で ある. 更にその所依の転換は声聞などにある鹿重を断捨することから得られる.

ここには以下のことが語られていると考えられる. 初地の見道において瑜伽行 者は唯識たることに悟入するが, そこでは「所取」「能取」,「見られるもの」「見 るもの」(客観主観) grāhyagrāhakaの二元性は消滅している. そしてその時は「無 心」の状態になっている，そしてその時には先述したように，(対象）境をあるが ままに見ているのであって，生来盲目の人が何も見ないのとは違う。すなわち， 瑜伽行者は生まれつき眼の見えない人が何も見ていないのとは違って何かを見て いる ${ }^{6}$, と安慧は云う。「唯識たることに心が安住する」その時は「所取能取」の 二元性が消滅した時であるが，「世間に向かって（まだ）活動することがないか ら」とあるから, 見道位を過ぎて修道位に入った訳ではない.つまり入無相方便 と呼ばれる宗教経験のクライマックスの時である. 唯識の他の文献に現われる, 無分別智における加行無分別智, 根本 (無分別) 智, 後得無分別智の中の根本智 の境位である。そこには概念構想は介入しないから言語表現はできない. した がってそれは「花」とか「机」とか云えないものであるから，「何かあるもの」 と取りあえず云うことにする.

\section{4.「唯識たること (唯識性)」における二義}

このように世親の偈頌と安慧の注釈には「唯識たること(唯識性)」が語られ, この「唯識性」には「心」ということについて相反する二義が語られている.

「唯識性」の第一の側面は, 根本智に打ける「所縁」は「心の内なるもの ${ }^{7)} 」$ と して成立しているということである，「心の内なるもの」と云っても，迷いの意 識における「唯識無境」「万法唯識」の, 一切は我が心の現われという「心の内」 とは違う。「所取」「能取」の二元性はすでに消滅しており, 見られているものは 悟りの世界としての「教説としての所縁, 教誡としての所縁, 通常の色声などの 所縁」である.「教誡」というのは仏教倫理と考えられるから, これも広い意味の 
教説として考えられるであろう。そのような「教説と色声など」を瑜伽行者は, 悟りの「唯識性」において「心の内なるもの」として見ている（把握している）, と述べられている。

「唯識性」の第二の側面は,「見るもの(「能縁」)」は「無心 acitta」であるから 「無」になっており，いわば「見る自己なくして」「見られるもの (所縁)」は見ら れている. 即ち第二の側面の基本的な立場は「無心 acitta」というかたちで，「見 る自己」が消えているということである. 第一の側面と第二の側面とは, 「心」と いうことについて,「心のみ [が存在する]」と「心は存在しない」というかたち で, 相反する構造になっている.

\section{5.「何かあるもの」と実在}

第一の「唯識性」と第二の「唯識性」との関係の形は, 第一の「唯識性」から 第二の「唯識性」への進展の関係であると考えられる，ここで「進展」という表 現をするのは, 大乗という仏道のプロセスで考えるならば,「無心」という語で 表現される「空思想」は大乗の仏道の究極に位置するのだから, 自然な表現であ ると考えられる.

そしてそこでは, 「教説としての所縁, 教誡としての所縁, 通常の色声などの 所縁」とあるから, 教説・教誡だけでなく色声香味触の一切が, ありのままに真 実に把握されているということになる。 そしてこれらの教説と世界の一切存在は 「心の内なるもの」の段階でばかりでなく，「進展」した段階の「無心」において も把握されていると考えられる。『安慧橎』では, 「進展」した「無心」の段階が 語られる以上，「無心」の段階での教説・世界の一切存在こそが「実在」であっ て,「心の内なる」教説・世界の一切存在は, まだ「観念性」を充分脱し切れて いないと考えられる。「心の内なるもの」としての「唯識性」には，なお観念性 が残っていると考えられる。「心の内なるもの」という限定があるからである. 従ってこの段階はまた「実在」に至る前段階にあると考えられる.

本稿3において述べたように，瑜伽行者は「入無相方便」において「何かある もの」を把握するが,「無心」において顕現している「何かあるもの」こそが「実 在」と呼べるものである.

\section{6. 結論}

安慧によると，「見道」の悟りにおいて瑜伽行者は「唯識性」に到達するが， 
「唯識性」には「心の内なるもの」と「無心」との二つの境位が語られている. この「無心」の境位において「何かあるもの」即ち「実在」が現前し, そのこと によって独我論ではないかという疑念は消滅する.

一方で, この「何かあるもの, 実在」の語が表現するものは, 西洋哲学, 例えば カント哲学で語られる「実在 (Realität)」とはかなり相違していると考えられる ${ }^{8)}$.

1）テキストはBuescher 2007 底本とした，以下B本と略号を使用。また Lévi 1925 を 適宜参照した．以下 Lévi 本と略号を使用．又この作品を略して『安慧釈』とする.

2）原文は “yadā tv ālambanaṃ jñānam naivopalabhate tadā / sthitạ̣ vijñaptimātratve grāhyābhāve tadagrahāt//”（28） B 本，p. 50. Lévi 本は jñānam を vijñānam とし，かつ vijñaptimātratve を vijñānamātratve としている. p. 43.

3）「対象（境）をあるがままに見るからであって，生来盲目の [人の］如くに［見ない の] ではない」の原文は “yathābhūtārthadarśanān na tu jātyandhavat” 蔵訳は don yang dag pa ji lta ba bzhin du mthong la $\mid$ dmus long lta bu ni ma yin pa D, no. 4069, 340-4, P, no. 5565, 200a-8 この梵文についての他の研究者の訳を挙げておく．宇井 1952，146：「如実の境を見るの であるから, 決して, 生得の盲者の如くではないのであるから,」. 山口・野澤 1953, 395：「境を如実に見る故に，生盲が〔境をみざる〕如くでない」. 荒牧 1976, 182：「もと よりあるがままに真理をみているからであって，生来の盲目であるからではないのであ るが,」.

4）「無心」の原語は acittahであり, acittaḥのンパウンドは, citta は中性名詞で男性名詞 に変形しているからバフブリヒであり，形容詞である，普通バフブリヒは「〜をもてる (人)」という訳になり，予想される「人」はこの場合「悟った瑜伽行者」であろうが, 文脈ではかかるべき適切な語が見当たらない，従ってこの形容詞は「心を持たないもの」 と訳すのが適切であろう。したがって『安慧橎』のこの箇所の acitta は, 厳密に云えば 「心をもたないもの」ということである。にもかかわらず本稿では従来一般的に使用さ れて来ている「無心」の訳語を使用することにするが, 理由は読者の読みやすさを配慮 してのことである.「無心」の語は漢訳以来代表的な仏教語の一つ（中村 1975, 1335）で あって, 研究者には馴染み深く読みやすい, と考えられる. 荒牧 1976, 183 も「心がなく なっているもの (無心)」と訳して「無心」の語を残している. 思想的には, 「心をもた ないもの」の訳でも，悟った瑜伽行者が心をもたないという形での，心についての否定 が成立している点で「無心」の語と同じであり，この心についての否定において大乗仏 教の空思想が顕現しているということが重要である.

5）「(不) 可塑性」の原語は karmaṇyatā. Böhtlingk, pw は adj. a) im Werke gewandt, geschickt; fleissig. b) zur Verrichtung heiliger Handlungen geeignet. c) günstig für eine Unternehmung. karmaṇyatā でf. Tätigkeit, Wirksamkeit. Monier-Williams は karmaṇya で mfn. skillful in work, clever, diligent. proper or fit for any act, suitable for a religious action. karmanyatā で cleverness, activity. Lokesh Chandra は las su rung pa, p. 2308.

6）この箇所の調伏天の復注の和訳は,「たとへ了得せずともそれ〔所縁〕を如実に見る のであるから, 生盲の如く〔視〕力なきために〔見ない〕のではない」.（山口・野澤 1953, 396）調伏天の原文は dmus long bzhin du mthu med pa ni ma yin pa『唯識三十頌安慧釈復 疏』D no. 4075, 119-5. P no. 5571, 65b-4. 
7）第28頌の偈頌と注釈において，瑜伽行者は「唯心性（cittamātratā）に安住するとき」 「その時に教説としての所縁，教誡としての所縁，通常の色声などの所縁を智は心より 外に受けとらない」とあることを踏まえている.

8）源 1996参照.

〈参考文献〉

Buescher, Hartmut, ed. 2007. Sthiramati’s Triṃśikāvijñaptibhāṣya. Wien: Verlag der Österreichischen Akademie der Wissenachaften.

Lévi, Sylvain, ed. 1925. Vijñaptimātratāsiddhi. Paris: Librairie Ancienne Honoré Champion.

荒牧典俊 1976 「唯識三十論」長尾雅人・梶山雄一・荒枚典俊訳『大乗仏典 15 世親論集』 中央公論社.

宇井伯寿 1952 『唯識三十頌釈論』岩波書店.

中村元編 1975 『仏教語大辞典』東京書籍.

源重浩 1996 「カントにおける「本来の自己」の問題」日野賢隆先生還暦記念会編『仏教そ の文化と歴史 日野賢隆先生還暦記念』永田文昌堂, 411-439.

— $2017\lceil$ 安慧の「何かあるもの」と実在の問題——初期唯識思想と独我論—」『南 アジア古典学』12: 173-189.

山口益・野澤静証 1953 『親唯識の原典解明』法蔵館.

〈キーワード〉 安慧, 唯識性, 二義性, 何かあるもの, 実在

(熊本県立大学非常勤講師)

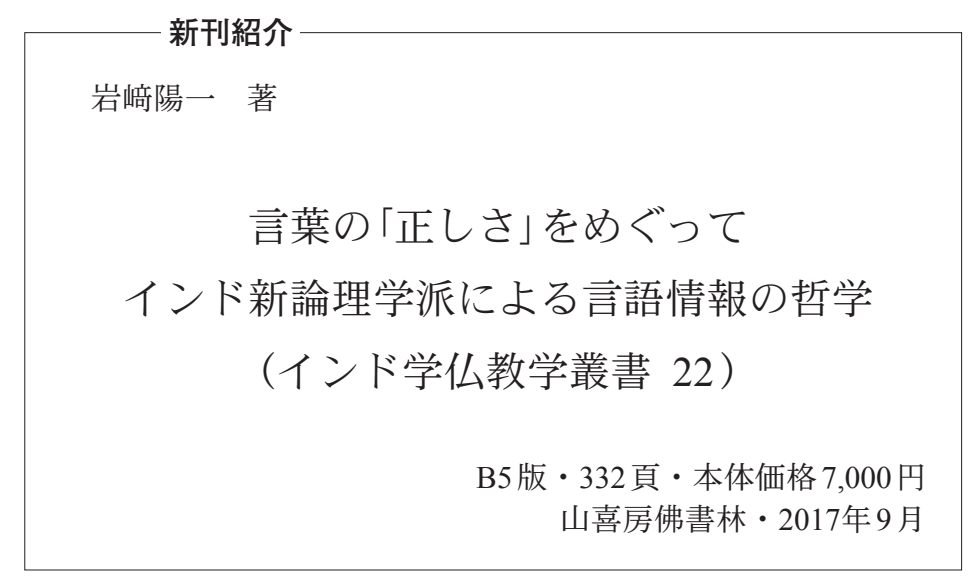

